\title{
A Study on Active Learning Way of Intercultural Communication Courses for Business Majors
}

\author{
Dingjie Xu \\ Department of Business Management \\ Chongqing College of Electronic Engineering \\ Chongqing, China
}

\begin{abstract}
This thesis tries to introduce active learning in intercultural communication courses. Students can be placed in an actively inquiring, problem solving, and language exchanging environment. In active learning, students will independently access to knowledge resources, understand their own learning process of communication skills and accumulate learning strategies.
\end{abstract}

Keywords-intercultural communication; active learning; teaching deign; teaching objective; teaching strategies; learning evaluation

\section{INTRODUCTION}

Intercultural communication is a comprehensive concept, including three aspects of ability:

- Pronunciation, vocabulary, syntax and semantics of context, language ability, social linguistic competence and cultural competence of pragmatic competence.

- Non-verbal communication ability.

- Cultural adaptability.

In brief, the application of intercultural communication should include the following aspects:

- Identifying the specific language and nonverbal behaviors of the learned culture, and explain their functions

- Being familiar with the language and behavior habits of people in various emergency situations and daily situations;

- being Familiar with the connotation and extension of language vocabulary including its cultural meaning;

- Understand the language characteristics of people from different social backgrounds (such as gender, age, class, and the education level, etc.) and express different interpersonal relationships in appropriate language;

At present, students are taught by domestic teachers and also teachers from different countries and cultural backgrounds Outside the classroom, collision of frequent communication across different cultures, cultural differences, and social background also affects the students' intercultural communication level. Under the background of globalization and integration, students majoring in international trade are facing more complex and intuitive intercultural communication. Intercultural communication teaching objective for international trade majors is bound to ensure that their intercultural communication ability can be effectively expanded.

Intercultural communication courses can initiate active learning ways. At present, students in intercultural communication courses are of low motivation and lacking of language skills practice. In view of solving these problems, this paper studies the new learning way in intercultural communication courses for international trade majors--active learning in intercultural communication course.

\section{ACTIVE LEARNING CONCEPT}

"Active learning" is advocated in North America in the last century to get rid of traditional explanation in education, from $70 \mathrm{~s}$ to $80 \mathrm{~s}$ last century, especially since the $90 \mathrm{~s}$, it became a trend in today's world education reform. In active learning, participate evolved in writing, speaking, publishing, etc., while the accompanying cognitive process is externalized. Here the cognitive process refers to the perception, memory, language, thinking (logical thinking)/critical thinking, creative thinking, reasoning, judgment, decision making, problem solving, etc. "Active learning" means a paradigm shift from teaching to learning.

The basic theory of "active learning" is the theory of "meaningful learning experience" which is characterized by high participation of students in high energy. L.d. Fink has comprehensively discussed how to create "meaningful learning experience", from teaching objectives to teaching composition, teaching strategy and achievement evaluation. In his opinion, "active learning" is different from "passive learning". "Active learning" is "the involvement of students in activities and thinking about activities". So-called "meaningful learning" can be interpreted as: "the basic knowledge to (the understanding of the key concepts, terminology, and relationship with memory), using (method) applied knowledge and integration (to revealing the theme of the relationship between subject and other), human dimensions (subject to study, personal and social enlightenment), learning interest, interest, continuous learning, and study method of the study, shows that beyond the acquisition of knowledge and skills, attitude of training, involving a wide range of personality growth target, arguably, 
systematically, include to show the student's learning and growth". The general characteristics of "active learning" are further summarized by C.Bonwell: 1 . Students engage in active learning activities beyond the "listening". 2. Focus on the cultivation of students' skills rather than the transmission of information. 3. Students develop high-order thinking (analysis, synthesis, evaluation). Students actively participate in activities such as reading, discussing and writing. 5. Students focus on their own attitudes and values. 6. Externalization of cognitive processes.

The cognitive process of active learning refers to the perception, memory, language, thinking (logical thinking)/critical thinking, creative thinking, reasoning, judgment, decision making, problem solving, such as information processing. Active learning focuses on getting rid of the simple "listening" and paying attention to "speaking, writing and expressing".

In the course of intercultural communication, the course aims to improve the communication ability, and the teaching form is to listen, speak, read and write. Active learning was supposed to have active participation, emphasizing thinking analysis,, make good use of language as information carrier, and take advantages of active learning, will promote learners to improve intercultural communicative competence. It is necessary to pay attention to the content selection of active learning in intercultural communication.

Active learning in intercultural communication is a learning process of emphasizing contextual communication, problem solving procedures, autonomy of knowledge construction, and practice of negotiation and communication.

Features of active learning are intercultural communication courses.

\section{A. Contextual Active Learning in Intercultural Communication Courses}

Active learning in intercultural communication emphasizes that students obtain experience through independent practice. For the sake of solving contextual problems, intercultural communication should use appropriate language in Intercultural communication course. For international trade majors, they will involve in special purpose language, also involves foreign trade background, business background, so learning content itself is of contextual and conversational features.

\section{B. Conversational Active Learning in Intercultural Communication Courses}

The improvement of intercultural communication competence is based on the interaction, dialogue, discussion, consultation and cooperation between learners. Active learning used language or special purpose language as the carrier of communication, so that students can make full use of language, achieve the goal of practical language skills, and finally improve the ability of intercultural communication.

\section{LEARNING OBJECTIVES OF ACTIVE LEARNING IN INTERCULTURAL COMMUNICATION COURSES}

The goals of active learning in intercultural communication courses:

- Enable learners to develop their ability to inquiry.

- Let learners do corporate learning in interpersonal communication and cultivate intercultural communication skills.

- Let learners reflect on their intercultural communication learning.

The learning project is not done individually, but in the form of a learning group. In teaching, it is not to let learners understand and remember, but to think and judge. As a result of active learning activities, learners not only acquire language skills, but also realize their own changes (growth).

\section{LEARNING DESIGN OF ACTIVE LEARNING IN INTERCULTURAL COMMUNICATION COURSES}

The author attempts to set up active learning in intercultural communication project to guide students' active learning in intercultural communication. Teacher designs the in-class active learning project that meets the learner's cognitive level. The project does not require students to pursue correct answers, but focuses on the combination of knowledge, communication skills, strategy and emotional attitude.

Each intercultural communicative learning project (unit) includes the following three steps: First, set up intercultural communication contextual project.

First, set up intercultural communication project. According to the learning theme of each unit, teachers set up contextual problems related to the teaching content. The content design conforms to the cognitive level of the learners and conforms to the most proximal development theory. The content and scope of the active learning in intercultural communicative project that the learner is to complete will need their participation in the exploration of the experience and results obtained.

Second, implement of intercultural communication project. Learners can complete the active learning in intercultural communication project in the classroom and out of the classroom by means of data collection, language exchange, information exchange and discussion. In the course of learning, students should set up own portfolio of intercultural communication. In the process of learning with partners, finish notes while communicating.

The third step is the summary of the active learning in intercultural communication project (unit). Teachers and students should summarize and reflect on the process and results of intercultural communication. First of all, teachers guide students in active learning in intercultural communication project about the result of communication, teachers use "active learning in intercultural communication project comprehensive evaluation form" to test the students' language skills, and provide the evaluation opinions to students, improve students' intercultural communication skills. Second, to develop student's intercultural communication through 
complementing individual self-evaluation, mutual learning group, intentions to make learners to communicate effective learning strategies, exchange learning experience, share of experience in active learning in intercultural communication.

\section{TEACHING StRategies FOR ACTIVE LEARNING IN INTERCULTURAL COMMUNICATION}

\section{A. Set up the Intercultural Communication Practice Situation}

In intercultural communication course, the teachers determine the current practice of the "subject" around the "theme" create a real situation, and through the guide, stimulate students' curiosity, to inspire students' interest in learning.

The intercultural communication resources that the students contacted are extensive, and the content of textbooks has its limitations. So teachers in setting up practice content, to fully pay attention to the intercultural communication skills should based on reality, and be closely related to the work environment, both to students' cognitive characteristics and interest. The practical content can be derived from real international trade pragmatic environment.

The most significant characteristic of active learning is to return the initiative of learning to the students. In order to overcome the students' poor planning problems in the practice of learning process, teachers should guide students' learning goals, avoid the learning purpose is not clear; cannot meet the teaching aim of learning activities.

As the active learning in intercultural communication, learners should also be timely summarizing the results of a recent study, setting a learning goal, enhance a more effective intercultural communication practice in the future.

\section{B. Focus on the Output of Intercultural Communication}

The purpose of carrying out active learning in intercultural communicative learning is to promote communication to achieve the aim of improving communicative competence.

In the process of intercultural communication, learners accumulate the language information and information materials, and firstly, they should have a clear understanding of the practical goals of intercultural communication. Learners should read and skim the collected materials. When accumulating information and language materials, pay attention to record the key information, experience, and to organize, analyze and summarize effectively.

Active learning in intercultural communication expands comprehensible language input and language skills, also expand through oral interpretation and written description of learning results. Learners can improve their thinking ability by using language to test and promote their own language absorption. Therefore, in the process of active learning and implementation of intercultural communication, we should make full use of the characteristics of the language and encourage students to think in multiple language systems and promote each other. In the process of intercultural communication, we should listen, read, write and speak more, and we will learn to read and write.

\section{REASONABLE LEARNING EVALUATIONS FOR ACTIVE LEARNING IN INTERCULTURAL COMMUNICATION}

\section{A. Diversified Evaluation for Learners}

Teachers should adopt diversified evaluation methods for intercultural communication courses. In this paper, the researchers think summarize evaluation (test) can test student's intercultural communication with exact scores, but formative assessment can assort learner's learning experience.

Self-evaluation and group evaluation ("Table I", "Table II") should be included in the evaluation of students' formative performance. In addition, in order to get fully understanding of students' ability in intercultural communication. Teachers can use comprehensive evaluation methods besides students' selfevaluation and group evaluation.

TABLE I. SELF-EVALUATION FORM FOR ACTIVE LEARNING IN INTERCULTURAL COMMUNICATION

\begin{tabular}{|l|l|l|l|}
\hline $\begin{array}{c}\text { active learning in } \\
\text { intercultural communication }\end{array}$ & Agreed & $\begin{array}{c}\text { Partly } \\
\text { agreed }\end{array}$ & Not agreed \\
\hline $\begin{array}{l}\text { Our learning procedures are in } \\
\text { accord with teacher's } \\
\text { instruction. }\end{array}$ & & & \\
\hline $\begin{array}{l}\text { We consult our teachers and } \\
\text { learning partners when not } \\
\text { understanding }\end{array}$ & & & \\
\hline $\begin{array}{l}\text { We express our opinions while } \\
\text { learning }\end{array}$ & & & \\
\hline $\begin{array}{l}\text { We do analyzing and sharing of } \\
\text { learning materials }\end{array}$ & & & \\
\hline $\begin{array}{l}\text { We listen carefully to others } \\
\text { expressions. }\end{array}$ & & & \\
\hline $\begin{array}{l}\text { We take advantage of effective } \\
\text { learning resources }\end{array}$ & & & \\
\hline $\begin{array}{l}\text { We participate in the } \\
\text { discussion. }\end{array}$ & & & \\
\hline $\begin{array}{l}\text { Our active learning in } \\
\text { intercultural communication is } \\
\text { productive. }\end{array}$ & & & \\
\hline
\end{tabular}

TABLE II. GROUP EVALUATION FORM FOR ACTIVE LEARNING IN INTERCULTURAL COMMUNICATION

\begin{tabular}{|l|l|l|}
\hline Active learning in intercultural communication & YES & NO \\
\hline $\begin{array}{l}\text { Our active learning group does the communication } \\
\text { and discussion together. }\end{array}$ & & \\
\hline $\begin{array}{l}\text { Every member has a chance to contribute opinion, } \\
\text { and our discussion is effective and productive }\end{array}$ & & \\
\hline $\begin{array}{l}\text { We take note of learning and make a summary of } \\
\text { our learning outcomes. }\end{array}$ & & \\
\hline Our oral, written presentation is successful. & & \\
\hline $\begin{array}{l}\text { We search various materials to finish our learning } \\
\text { project. }\end{array}$ & & \\
\hline
\end{tabular}

Lu Ziwen (2008), the assessment of language skills is of learners' reading, writing, listening and speaking ability

In order to promote language skills, teachers should examine learners' language skills from different aspects. Therefore, language skills testing should be comprehensive. The most typical evaluation is comprehensive evaluation; it can evaluate learners' ability of information retrieval, information processing, concept drafting, evaluation, etc. 
Referring to the comprehensive evaluation form of the learning project, Lu Ziwen (2008), the author sets up a comprehensive evaluation table for active learning in intercultural communication ("Table III").

TABLE III. COMPREHENSIVE EVALUATION TABLE OF ACTIVE LEARNING IN INTERCULTURAL COMMUNICATION COURSES

\begin{tabular}{|c|c|c|c|c|}
\hline $\begin{array}{l}\text { Language } \\
\text { ability }\end{array}$ & Language performance & $\begin{array}{c}1 \\
\text { points }\end{array}$ & $\begin{array}{c}2 \\
\text { points }\end{array}$ & $\begin{array}{c}3 \\
\text { points }\end{array}$ \\
\hline Grammar & $\begin{array}{l}\text { Language in tenses, gramm } \\
\text { ar, syntax, spelling } \\
\text { correctly. }\end{array}$ & & & \\
\hline Style & $\begin{array}{l}\text { Selection of } \\
\text { Vocabulary and syntactic st } \\
\text { ructure are in line with the } \\
\text { project context. }\end{array}$ & & & \\
\hline Structure & $\begin{array}{l}\text { The results have a detailed } \\
\text { body part and a reasonable } \\
\text { ending }\end{array}$ & & & \\
\hline Statement & $\begin{array}{l}\text { Can clearly show the results } \\
\text { of the work, language with } \\
\text { less grammar mistakes. }\end{array}$ & & & \\
\hline Effect & $\begin{array}{l}\text { Be able to clearly state your } \\
\text { point of view and get unani } \\
\text { mous approval from other } 1 \\
\text { earners }\end{array}$ & & & \\
\hline
\end{tabular}

\section{CONCLUSION}

Active learning in intercultural communication course of international trade majors is helpful to create an open learning environment and provide students with opportunities to improve intercultural communication skills. At the same time, teachers can design learning content of contextual, active, communicative features, and lead students to find a way of autonomous learning.

\section{REFERENCES}

[1] Kim, Y.Y. 1991. Intercultural communication competence: a systemstheoretic view. International and Intercultural Communication Annual. New bury Park, CA: Sage.

[2] Lu Ziwen. Methodology and strategy of English teaching. huadong normal university, shanghai. 2008.

[3] "Mosaic Active Learning Initiative launches in select classrooms." Inside IUPUI.N.p.,27 Sept.2016. Web.

[4] Carl Straumsheim. "Indiana's Active-Learning Mosaic Expands." Inside Higher Ed. N.p., 12 May. 2017.

[5] Zhong Qiquan. "Active learning: the transformation of teaching paradigm." Research in Educational Development. Shanghai. August.2017. 